\title{
Understanding Heat Stress Tolerance of Suspended Cells in the Model Plant Populus euphratica
}

\author{
Joana Silva-Correia, ${ }^{1,2}$ Herlânder Azevedo, ${ }^{1}$ Teresa Lino-Neto, ${ }^{1}$ and Rui Manuel Tavares ${ }^{1}$ \\ ${ }^{1}$ Plant Functional Biology Centre, Centre for Biodiversity, Functional \& Integrative Genomics, \\ University of Minho, Gualtar Campus, 4710-057 Braga, Portugal \\ ${ }^{2}$ 3B's Research Group, Biomaterials, Biodegradables and Biomimetics, University of Minho, Headquarters of the European Institute of \\ Excellence on Tissue Engineering and Regenerative Medicine, AvePark, 4806-909 Caldas das Taipas, Portugal \\ Correspondence should be addressed to Joana Silva-Correia, joana.correia@dep.uminho.pt
}

Received 1 February 2012; Accepted 15 March 2012

Academic Editors: N. Gierlinger, D. Huber, B. Schirone, and S. Sun

Copyright ( $\odot 2012$ Joana Silva-Correia et al. This is an open access article distributed under the Creative Commons Attribution License, which permits unrestricted use, distribution, and reproduction in any medium, provided the original work is properly cited.

A comprehensive understanding of the physiological responses of plants to extreme temperatures is essential for future strategies for plant improvement. Obvious advantages can result from the study of highly adapted plant species, such as the model tree Populus euphratica Olivier that naturally thrives under extreme temperatures, saline soils, and drought. The present paper addresses the issue of $P$. euphratica thermotolerance using a cell suspension model system. $P$. euphratica suspended cells were subjected to a range of temperatures (from 5 up to $75^{\circ} \mathrm{C}$ ) for $20 \mathrm{~min}$, and cultures were evaluated for cell viability and biomass content at specific time points. The results have shown that cell viability was only affected after a temperature stress higher than $40^{\circ} \mathrm{C}$, although in these conditions it was observed that a cell growth increases after the recovery period. In contrast, a total decline in cell viability was observed in suspended cells treated at $50^{\circ} \mathrm{C}$ or higher temperatures, which did not show growth recovery capacity. Therefore, the known natural tolerance of P. euphratica to thermal stress was not observable at the cellular level. The greater susceptibility to high temperatures in suspended cells as compared to field plants suggests that high thermotolerance can only be achieved when cells are integrated into a tissue.

\section{Introduction}

Plants often grow under unfavorable conditions that extensively alter their development and productivity. One such environmental challenge is exposure to adverse temperatures, which can significantly affect many essential metabolic processes and disrupt an extensive range of cellular components. Heat stress can vary in severity, depending upon the intensity and extent of the stress as well as the rate of temperature variation. As sessile organisms, plants have developed several metabolic responses that minimize injuries caused by the constant exposure of plants to daily temperature fluctuations and their association with other abiotic factors $[1]$.

The deeper knowledge on plant abiotic stress resistance has been fundamental in the development of effective engineering strategies leading to enhanced stress tolerance. Plant transformation with genes conferring thermal tolerance has been successfully achieved $[2,3]$. However, many molecular mechanisms involved in thermotolerance are likely still unknown. A successful strategy for the assignment of gene function has been the study of species that are naturally adapted to survive in extreme environments. The advantages of using members of the poplar genus (Populus) as genomic models for tree molecular biology have been extensively reported [4, 5]. Among Populus species, P. euphratica Olivier shows a remarkable survival capability, presenting high growth yields when facing high soil salinity, extreme temperatures $\left(-45^{\circ} \mathrm{C}\right.$ to $\left.+54^{\circ} \mathrm{C}\right)$, and drought [6]. Such conditions are typically found in semiarid areas over a longitudinal extent that ranges from China to Spain and from south Kenya to Kazakhstan, where P. euphratica is naturally distributed [7]. However, despite being known as a plant tolerant to extreme temperatures in its natural habitat, 
the biological mechanisms behind these observations remain largely unknown.

The level of tolerance that a given plant displays depends on the species, tissue, or cell type considered [8]. In multicellular organisms, the elucidation of cell-level thermotolerance mechanisms can be as difficult as it is impractical. The utilization of in vitro cell systems has long been a useful strategy to reveal cellular responses that would otherwise be hidden at the whole-plant level. Indeed, several specific features highlight the attractiveness of in vitro cultured cells as a system to study stressed-cell responses. Cell cultures rapidly generate a great amount of cell material with reduced cellular complexity. More importantly, studies carried out in this kind of tissue culture allow to completely control the homogeny of cell response and environmental parameters. Cell cultures also allow a number of quantitative studies in which compounds can be simply added or removed from the medium and cell aliquots can be easily harvested. Moreover, cells in culture are relatively easy to assess, and a large amount of data can be easily obtained for each treatment [9]. A number of protocols to establish stable cell suspensions for studying plant heat stress responses have been reported from several plant species. Therefore, it is well established that cell suspension cultures could be beneficial when studying thermotolerance mechanisms among forest species. The particular use of $P$. euphratica suspension cultures has already been reported in saline and osmotic tolerance studies [10, 11]. However, to our knowledge, no studies concerning thermotolerance in this system have yet been reported. The aim of the present work was to evaluate the heat stress tolerance capacity of $P$. euphratica suspension cell cultures. Suspended cells were subjected to a range of temperatures, and cultures were characterized for cell viability and biomass content at regular time points in the growth cycle.

\section{Materials and Methods}

2.1. Establishment and Maintenance of Populus euphratica Suspension Cell Cultures. P. euphratica Olivier calli were kindly provided by $\mathrm{Gu}$ et al. [12] and used for the induction of suspension cell cultures. Cell cultures were initiated by transferring 1 to $2 \mathrm{~g}$ of 4 -week-old callus tissue to $70 \mathrm{~mL}$ of Murashige and Skoog (MS) medium [13] supplemented with $0.5 \mathrm{mg} / \mathrm{l}$ 1-naphthaleneacetic acid (NAA), $0.25 \mathrm{mg} / \mathrm{l}$ benzyladenine (BA), and $2.5 \%(\mathrm{w} / \mathrm{v})$ sucrose, at $\mathrm{pH} 5.5$. Cultures were maintained in $250 \mathrm{~mL}$ flasks at $25^{\circ} \mathrm{C}$ with continuous shaking $(125 \mathrm{rpm})$ in the dark. Cell-suspension subculturing was performed every 12 days by transferring $10 \mathrm{~mL}$ of cell culture into $60 \mathrm{~mL}$ of fresh medium. A sustainable culture was obtained after four subculture cycles, when a fine suspension of cells was observed.

2.2. Characterization of Cell Growth. Cell growth was monitored by the estimation of cell suspension dry weight. Periodically, $3 \mathrm{~mL}$ aliquots of suspended cells were harvested and filtered using a piece of preweighted filter paper (Whatman). Dry weight was determined after oven drying at $60^{\circ} \mathrm{C}$ for $24 \mathrm{~h}$. This procedure was repeated every 2 days over a total period of 16 days. Biomass values were transformed into their natural logarithms for calculations of specific growth rate $(\mu)[14]$.

2.3. Imposition of Heat Stress. To determine the temperature that results in cell death, the response of suspended $P$. euphratica cells to temperature stress was evaluated by subjecting suspension cultures to a range of temperature treatments (from 5 up to $75^{\circ} \mathrm{C}$ ). Flasks containing mid-log phase cell suspensions (day 6 of growth) were immersed into a water bath at one of several different temperatures $\left(5,15,25,35,40,45,50,55,65\right.$, and $\left.75^{\circ} \mathrm{C}\right)$ for $20 \mathrm{~min}$, with continuous shaking. After temperature stress, the cells were transferred into another water bath at $25^{\circ} \mathrm{C}$ for $10 \mathrm{~min}$ to reestablish the typical growth temperature. Suspension cultures were then returned to the previous incubation conditions $\left(25^{\circ} \mathrm{C}\right.$, with $125 \mathrm{rpm}$ continuous shaking, in the dark). At regular intervals, cell aliquots were collected for quantification of cell viability and dry weight.

2.4. Determination of Cell Viability. Analysis of cell viability was performed before the imposition of the 20 min temperature stress, after recovery at $25^{\circ} \mathrm{C}$ for $10 \mathrm{~min}$ and at regular intervals. The viability of suspended cells was measured using the trypan blue exclusion method [15]. Aliquots containing $150 \mu \mathrm{L}$ of cell culture were gently mixed with an identical volume of $0.4 \%(\mathrm{w} / \mathrm{v})$ trypan blue (Sigma-Aldrich) and incubated in the dark for $10 \mathrm{~min}$. A $50 \mu \mathrm{L}$ sample was observed under a Leica ATC 2000 light microscope, and the number of viable (unstained) and dead (stained) cells was subsequently determined. Cell viability was calculated as the percentage of viable cells out of the total number of cells observed. Results are represented as mean values of twenty independent cell counts ( $>50$ cells per count). Whenever cell death was observed, viability values were converted into their natural logarithm for specific death rate determination.

\section{Results}

Fine, stable cell suspension cultures with small cell aggregates and single cells are required for controlling the uniformity of environmental and physiological parameters. A cell suspension culture was established from $P$. euphratica callus tissue, which was subcultured every 12 days in fresh MS medium. The suspended cells grew vigorously with each subculture, maintaining small clusters made up of a few cells. After a short adaptation period during the first two days of subculture, cell suspensions started an exponential growth phase (specific growth rate of $0.21 /$ day) that lasted for 8 more days. The biomass continued to increase until day 12, after which the growth rate leveled off, and cell degeneration and necrosis become apparent. These results indicate that cell suspensions should be subcultured at intervals no longer than 12 days for optimal growth. For subsequent thermotolerance studies, in which uniformity in the physiological state of the cells is required, cells in midexponential phase (day 6) were used.

The response of suspended P. euphratica cells to the imposition of a temperature stress was evaluated by treating the 


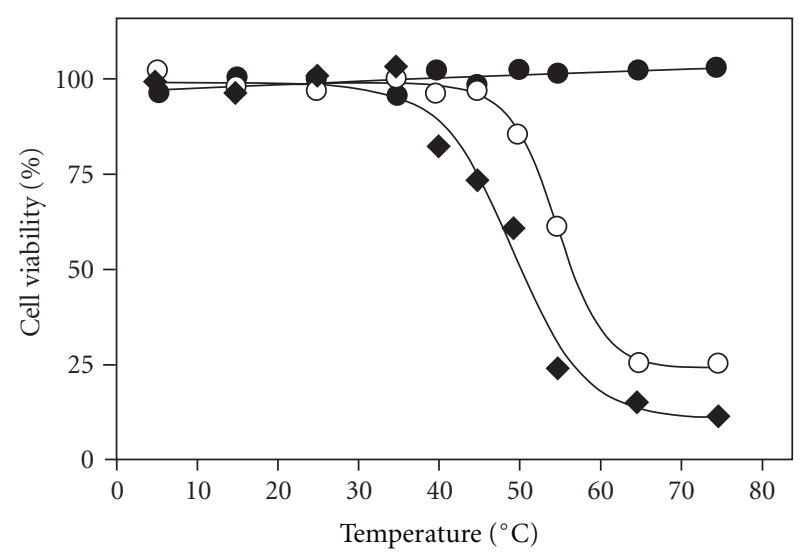

Figure 1: P. euphratica cell viability after $20 \mathrm{~min}$ exposure to different temperatures $\left(5\right.$ to $\left.75^{\circ} \mathrm{C}\right)$. Cell viability was determined by the trypan blue exclusion method immediately before heat treatment (-), after recovery at $25^{\circ} \mathrm{C}$ for $10 \mathrm{~min}(\mathrm{O})$ and for $20 \mathrm{~h}$ $(\checkmark)$. Results represented mean values of twenty independent cell counts ( $>50$ cells per count).

suspension cultures to a range of temperatures comprised between 5 and $75^{\circ} \mathrm{C}$. The analysis of cell viability corresponding to the two initial time points (before the imposition of the $20 \mathrm{~min}$ temperature stress and after recovery at $25^{\circ} \mathrm{C}$ for $10 \mathrm{~min}$ ) revealed that, during this period, cell viability was essentially unaffected for temperatures ranging from 5 up to $45^{\circ} \mathrm{C}$ (Figure 1). Incubation at $50^{\circ} \mathrm{C}$ resulted in slightly decreased cell viability (89\%), declining thereafter with increased temperature of the heat shock and reaching values near $25 \%$ for the highest temperature tested $\left(75^{\circ} \mathrm{C}\right)$. A null cell viability value was not achieved, which was probably due to the natural aggregation of plant cells, resulting in an inaccurate trypan blue viability measurement. When cell viability was evaluated $20 \mathrm{~h}$ after heat treatment, different levels of cell viability were obtained. A decrease in cell viability was observed for the $40^{\circ} \mathrm{C}$ heat treatment. Also, for heat treatments at higher temperatures, cell viability after $20 \mathrm{~h}$ of recovery was lower than after $10 \mathrm{~min}$ of recovery. Altogether, these results suggest that heat treatment not only has an immediate effect on cells but also produced a longterm effect on cell viability. While the percentage of cell viability obtained immediately after heat treatment reflects the instant effect on cells, provoked by membrane damage or necrosis that instantly destroy the cells, the results obtained after $20 \mathrm{~h}$ reflect the activation of cell-defence mechanisms against temperature, leading or not to cell recovery, and therefore are seen as long-term effects.

Cell viability was further analysed upon stress treatment and during recovery at $25^{\circ} \mathrm{C}$ as a function of time over a maximum period of $80 \mathrm{~h}$ (Figure 2). Cell viability was significantly affected after heating at $55^{\circ} \mathrm{C}$. Although cell viability was still as high as $72 \%$ after heat shock $(0.5 \mathrm{~h})$, it rapidly declined to negligible levels $(\sim 16 \%)$ after $10 \mathrm{~h}$ at recovery temperature $\left(25^{\circ} \mathrm{C}\right)$. A more moderate cell death induction was observed after treatment at $50^{\circ} \mathrm{C}$. Cell viability after heat shock $(0.5 \mathrm{~h})$ remained high $(82 \%)$ but
Table 1: Specific death rates of $P$. euphratica cell suspensions after incubation for $20 \mathrm{~min}$ at different temperatures $\left(25\right.$ to $\left.75^{\circ} \mathrm{C}\right)$ followed by recovery at $25^{\circ} \mathrm{C}$.

\begin{tabular}{lc}
\hline Temperature & Specific death rate $(/ \mathrm{h})$ \\
\hline $25^{\circ} \mathrm{C}$ & 0 \\
$40^{\circ} \mathrm{C}$ & 0.007 \\
$45^{\circ} \mathrm{C}$ & 0.012 \\
$50^{\circ} \mathrm{C}$ & 0.026 \\
$55^{\circ} \mathrm{C}$ & 0.179 \\
$65^{\circ} \mathrm{C}$ & 0.543 \\
$75^{\circ} \mathrm{C}$ & 0.669 \\
\hline
\end{tabular}

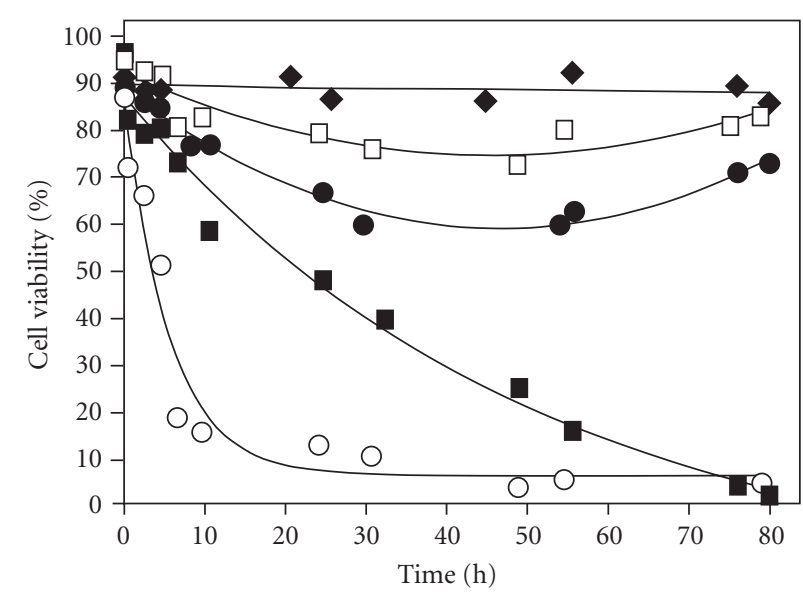

Figure 2: $P$. euphratica suspended cells viability after heat shock for $20 \mathrm{~min}$ at $25^{\circ} \mathrm{C}(\checkmark), 40^{\circ} \mathrm{C}(\square), 45^{\circ} \mathrm{C}(\bullet), 50^{\circ} \mathrm{C}(\boldsymbol{\square})$, and $55^{\circ} \mathrm{C}$ ( $\bigcirc$ ) and subsequent recovery at $25^{\circ} \mathrm{C}$, for up to $80 \mathrm{~h}$. Cell viability was determined by the trypan blue exclusion method. Results represented mean values of twenty independent cell counts $(>50$ cells per count).

progressively declined to very low values $(\sim 5 \%)$ after $75 \mathrm{~h}$ at $25^{\circ} \mathrm{C}$. For those heat-treated suspension cultures displaying signs of cell death (from 40 up to $75^{\circ} \mathrm{C}$ ), the specific death rates were determined (Table 1). Results also indicate the cell death induction in $55^{\circ} \mathrm{C}$ and $50^{\circ} \mathrm{C}$ heat-treated suspension cultures.

Resumption of cell growth was only observed after treatment at $40^{\circ} \mathrm{C}$ and $45^{\circ} \mathrm{C}$ (Figure 2). Immediately after heat shock $(0.5 \mathrm{~h})$, cells were not strongly affected, displaying $\sim 90 \%$ cell viability. However, an induction of cell death was evident after $45 \mathrm{~h}$ at recovery temperature, attaining cell viability values of $\sim 75 \%$ and $\sim 60 \%$, respectively. After $45 \mathrm{~h}$ and until the end of the experiment $(80 \mathrm{~h})$, both cell suspensions were able to recover their growth ability, reaching initial cell viability levels. Interestingly, a $50^{\circ} \mathrm{C}$ treatment resulted in total cell viability loss (no recovery), despite the significantly slow death rate over a long $(80 \mathrm{~h})$ recovery period, which might be indicative of cell fate reprogramming. The ability of cell suspensions to recover was also evident when determining culture growth parameters after treatment at different temperatures (from 25 up to $65^{\circ} \mathrm{C}$ ) (Figure 3). By following the time course of biomass content, 


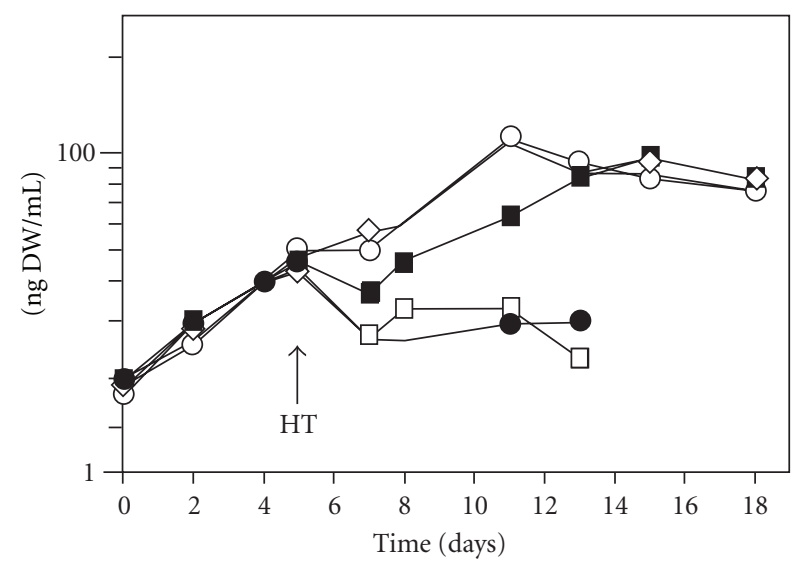

Figure 3: Dry weight of $P$. euphratica suspension cell cultures after incubation for $20 \mathrm{~min}$ at $25^{\circ} \mathrm{C}(\diamond), 35^{\circ} \mathrm{C}(\bigcirc), 45^{\circ} \mathrm{C}(\boldsymbol{\square}), 55^{\circ} \mathrm{C}(\square)$, and $65^{\circ} \mathrm{C}(\bullet)$ and recovery at $25^{\circ} \mathrm{C}$, over a total period of 18 days. Heat treatment (HT) was performed in the middle of exponential growth phase (day 5).

it was observed that treatment at $35^{\circ} \mathrm{C}$ did not affect the exponential growth phase of the suspension cultures. The recovery capacity of cell suspensions given a $45^{\circ} \mathrm{C}$ treatment was evident. After a period of decline corresponding to the first $45 \mathrm{~h}$ after heat treatment, the biomass content showed a progressive increase and reached maximum levels similar to those obtained with control suspensions $\left(25^{\circ} \mathrm{C}\right)$ but with a delay. In contrast, in suspension cultures incubated at $55^{\circ} \mathrm{C}$ and $65^{\circ} \mathrm{C}$, cell growth was completely impaired after treatment.

In summary, the incubation of suspended $P$. euphratica cells at $35^{\circ} \mathrm{C}$ did not affect their viability or growth, presenting a similar behavior as compared to that of control cells $\left(25^{\circ} \mathrm{C}\right)$. Suspension cultures only displayed susceptibility at temperatures higher than $40^{\circ} \mathrm{C}$. A heat-induced decline in cell viability was observable at $40^{\circ} \mathrm{C}$, but it was reversed during the recovery period. Although an extended decrease in viability was found in $45^{\circ} \mathrm{C}$ treated cells, cell growth was still able to recover. In contrast, suspended cells treated at $50^{\circ} \mathrm{C}$ or $55^{\circ} \mathrm{C}$ were not able to recover growth, and a complete decline in cell viability was registered. In more extreme heat treatments $\left(>55^{\circ} \mathrm{C}\right)$, growth cessation and accelerated cell death were observed.

\section{Discussion}

Incubation of suspended $P$. euphratica cells at temperatures above $55^{\circ} \mathrm{C}$ resulted in growth cessation and accelerated cell death, probably due to cell membrane damage and necrosis. This result is in agreement with previous reports on heat-treated $P$. euphratica leaf discs $\left(50^{\circ} \mathrm{C}\right.$ and $55^{\circ} \mathrm{C}$ for $30 \mathrm{~min}$ ), which have shown membrane damage as evaluated by electrolyte leakage [16]. These authors also suggested that P. euphratica plants can tolerate temperatures of $42^{\circ} \mathrm{C}$ for $54 \mathrm{~h}$ without adverse effects on survival. Using P. euphratica cell suspensions that were heat shocked for $20 \mathrm{~min}$, the temperature of $45^{\circ} \mathrm{C}$ corresponded to the highest sublethal temperature that was tolerated by cells.

Results from other culture systems in nontolerant species exhibited quite similar responses. Although the results cannot be strictly comparable because the heat treatments were applied just for $10 \mathrm{~min}$, in the well-documented Arabidopsis and tobacco species, suspension cultures can easily tolerate heat stresses lower than $45^{\circ} \mathrm{C}$ for 10 and 20 min, respectively $[9,17]$. The strongest induction of carrot and Arabidopsis cell death occurred at temperatures above $45^{\circ} \mathrm{C}$, attaining maximum levels at $55^{\circ} \mathrm{C}[9,18]$. The same results were also registered using suspended tobacco cells that were heat treated for $20 \mathrm{~min}$ [17]. In another study performed with tobacco cell suspensions treated for $10 \mathrm{~min}$, a timedependent effect on cell viability was found after incubation at $55^{\circ} \mathrm{C}$ [19]. This response was very similar to that observed in $P$. euphratica cultures subjected to temperatures of $50^{\circ} \mathrm{C}$ for $20 \mathrm{~min}$.

Heat stress has been reported as having a highly detrimental effect on the growth and metabolism of plants in their natural habitats. For in vitro P. euphratica plants, although no effects in survival were verified after prolonged exposure to temperatures of $42^{\circ} \mathrm{C}$, growth arrest was evident which can result from a reduction in the ability to photosynthesize [16]. In the present work, the high natural thermotolerance of the model tree P. euphratica (up to $54^{\circ} \mathrm{C}$ ) was not clearly evidenced by viability assays performed in suspended cells. In $P$. euphratica cell suspensions, heat treatments above $40^{\circ} \mathrm{C}$ for 20 min not only have an immediate effect on cell viability, but also induce subsequent cell death. Similar results have been reported in plant species that normally cannot manage environmental temperatures as high as those tolerated by $P$. euphratica plants in vivo. This could occur due to the higher sensitivity of suspended cells in sensing temperature alterations when compared to whole plants growing in the field. In addition, a suspended cell alone or within small cell aggregates would not have the same ability to cope with a heat-stress situation as a cell integrated into a system of multiple interacting cells. It is only when integrated into a tissue that cells would probably achieve the capacity to serve as fundamental units of tissue homeostasis and repair during stressful situations. Therefore, it would be expected that the thermotolerance mechanisms activated by elevated temperatures in nature may be induced by lower temperature levels in cell suspensions.

Other morphological or physiological features not generally considered to be part of the temperature tolerance machinery might also be responsible for the natural heat tolerance of $P$. euphratica plants. It has already been demonstrated that this species' strong capability to tolerate drought is mostly due to the development of effective roots to access deep water tables [20]. Also, the adaptation to highsalinity environments appears to be related to the ability to adapt to higher osmotic stress by keeping cell integrity and effectively controlling ionic toxicity [11]. It should also be noted that in vivo plants encounter a combination of several abiotic stresses rather than one individually. In drought-stricken areas, like the natural habitat of $P$. euphratica, a combination of drought and other stresses, 
such as heat or salinity, are encountered, and an integrated and unique response is employed by plants as the product of several interconnected responses [21, 22]. Therefore, we cannot exclude the possibility that the temperature tolerance presented by $P$. euphratica in the field, as demonstrated by the absence of related injuries, can be due to the capacity to achieve morphological or physiological modifications and/or overcome related stresses rather than specific thermotolerance mechanisms.

In the future, different approaches should be applied to take advantage of recently developed genomic and molecular tools for Populus. Also, the combination of genomic, proteomic and physiological approaches offers new possibilities for the elucidation of the function of the temperature stress machinery in Populus.

\section{Acknowledgments}

This paper was supported by Fundação para a Ciência e Tecnologia (POCTI/AGR/45462/2002). J. Silva-Correia's (SFRH/BD/16663/2004) and H. Azevedo's (SFRH/BPD/ 17198/2004) fellowships were supported by Fundação para a Ciência e Tecnologia.

\section{References}

[1] W. Wang, B. Vinocur, and A. Altman, "Plant responses to drought, salinity and extreme temperatures: towards genetic engineering for stress tolerance," Planta, vol. 218, no. 1, pp. $1-14,2003$.

[2] K. Iba, "Acclimative response to temperature stress in higher plants: approaches of gene engineering for temperature tolerance," Annual Review of Plant Biology, vol. 53, pp. 225-245, 2002.

[3] P. Bhatnagar-Mathur, V. Vadez, and K. K. Sharma, "Transgenic approaches for abiotic stress tolerance in plants: retrospect and prospects," Plant Cell Reports, vol. 27, no. 3, pp. 411-424, 2008.

[4] A. M. Brunner, V. B. Busov, and S. H. Strauss, "Poplar genome sequence: functional genomics in an ecologically dominant plant species," Trends in Plant Science, vol. 9, no. 1, pp. 49-56, 2004.

[5] S. Jansson and C. J. Douglas, "Populus: A model system for plant biology," Annual Review of Plant Biology, vol. 58, pp. 435-458, 2007.

[6] R. Gu and D. Pei, "Populus euphratica, a tolerant model but endangered arborescent species," Science Foundation in China, vol. 13, pp. 51-54, 2005.

[7] S. Wang, B. Chena, and H. Li, Euphrates Poplar Florest, China Environmental Science Press, Beijing, China, 1996.

[8] D. Y. Sung, F. Kaplan, K. J. Lee, and C. L. Guy, "Acquired tolerance to temperature extremes," Trends in Plant Science, vol. 8, no. 4, pp. 179-187, 2003.

[9] P. F. McCabe and C. J. Leaver, "Programmed cell death in cell cultures," Plant Molecular Biology, vol. 44, no. 3, pp. 359-368, 2000.

[10] T. Ma, Q. Liu, Z. Li, and X. Zhang, "Tonoplast $\mathrm{H}^{+}$-ATPase in response to salt stress in Populus euphratica cell suspensions," Plant Science, vol. 163, no. 3, pp. 499-505, 2002.

[11] R. Gu, Q. Liu, D. Pei, and X. Jiang, "Understanding saline and osmotic tolerance of Populus euphratica suspended cells,"
Plant Cell, Tissue and Organ Culture, vol. 78, no. 3, pp. 261265, 2004.

[12] R. S. Gu, X. N. Jiang, and Z. C. Guo, "Organogenesis and plantlet regeneration in vitro of Populus euphratica," Acta Botanica Sinica, vol. 41, no. 1, pp. 29-33, 1999.

[13] T. Murashige and F. Skoog, "A revised medium for rapid growth and bioassay with tobacco issue cultures," Physiologia Plantarum, vol. 15, no. 3, pp. 473-497, 1962.

[14] G. Godoy-Hernández and F. Vázquez-Flota, "Growth measurements: estimation of cell division and cell expansion," in Methods in Molecular Biology-Plant Cell Culture Protocols, V. M. Loyola-Vargas and F. Vázquez-Flota, Eds., pp. 51-58, Humana Press, Totowa, NJ, USA, 2005.

[15] B. H. Hou and C. G. Lin, "Rapid optimization of electroporation conditions for soybean and tomato suspension cultured cells," Plant Physiology, vol. 111, p. 166, 1996.

[16] S. Ferreira, K. Hjernø, M. Larsen et al., "Proteome profiling of Populus euphratica Oliv. upon heat stress," Annals of Botany, vol. 98, no. 2, pp. 361-377, 2006.

[17] E. Burbridge, M. Diamond, P. J. Dix, and P. F. McCabe, "Use of cell morphology to evaluate the effect of a peroxidase gene on cell death induction thresholds in tobacco," Plant Science, vol. 172, no. 4, pp. 853-860, 2007.

[18] P. F. McCabe, A. Levine, P. J. Meijer, N. A. Tapon, and R. I. Pennell, "A programmed cell death pathway activated in carrot cells cultured at low cell density," Plant Journal, vol. 12, no. 2, pp. 267-280, 1997.

[19] R. A. Vacca, M. C. De Pinto, D. Valenti, S. Passarella, E. Marra, and L. De Gara, "Production of reactive oxygen species, alteration of cytosolic ascorbate peroxidase, and impairment of mitochondrial metabolism are early events in heat shockinduced programmed cell death in tobacco bright-yellow 2 cells," Plant Physiology, vol. 134, no. 3, pp. 1100-1112, 2004.

[20] D. Gries, F. Zeng, A. Foetzki et al., "Growth and water relations of Tamarix ramosissima and Populus euphratica on Taklamakan desert dunes in relation to depth to a permanent water table," Plant, Cell and Environment, vol. 26, no. 5, pp. 725-736, 2003.

[21] H. Knight and M. R. Knight, "Abiotic stress signalling pathways: specificity and cross-talk," Trends in Plant Science, vol. 6, no. 6, pp. 262-267, 2001.

[22] R. Mittler, "Abiotic stress, the field environment and stress combination," Trends in Plant Science, vol. 11, no. 1, pp. 15$19,2006$. 

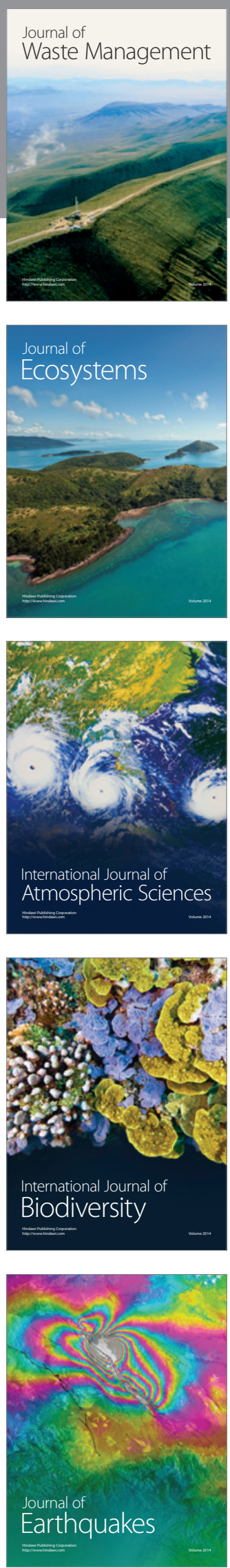
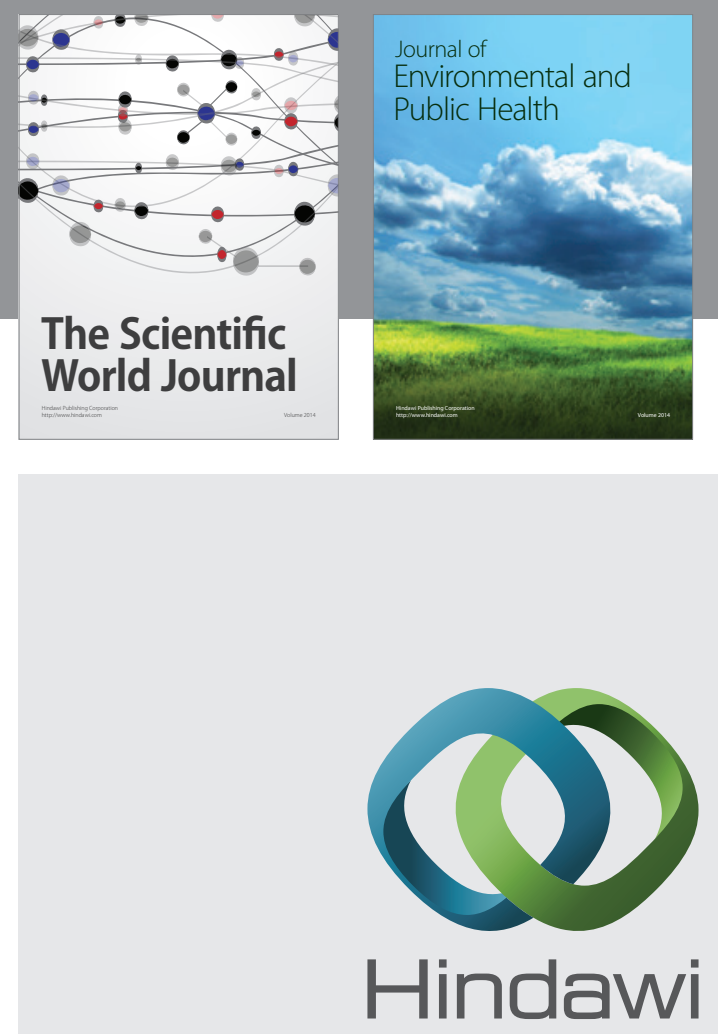

Submit your manuscripts at

http://www.hindawi.com
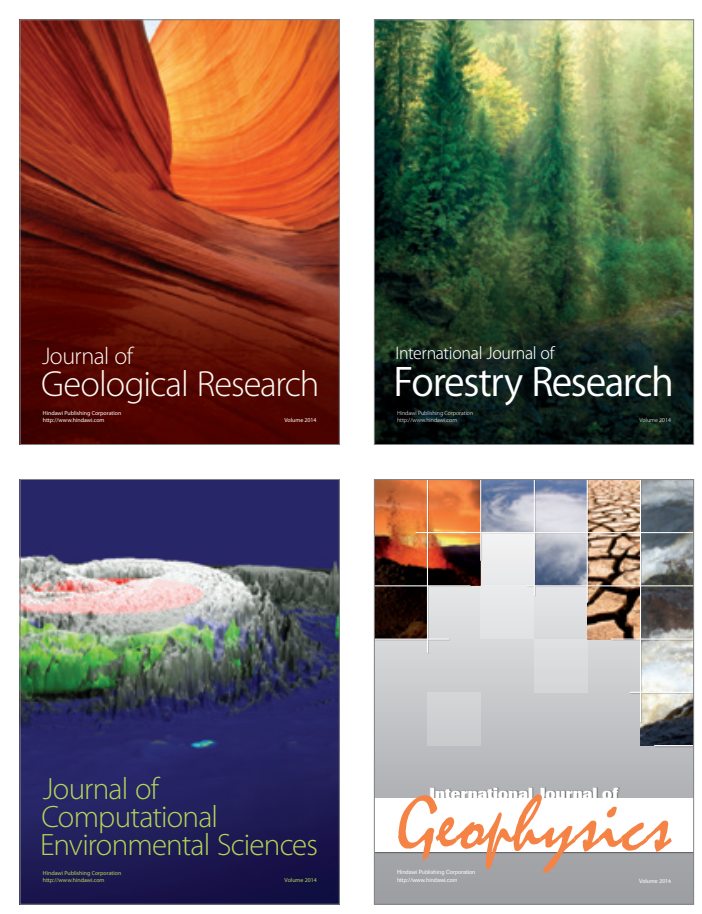
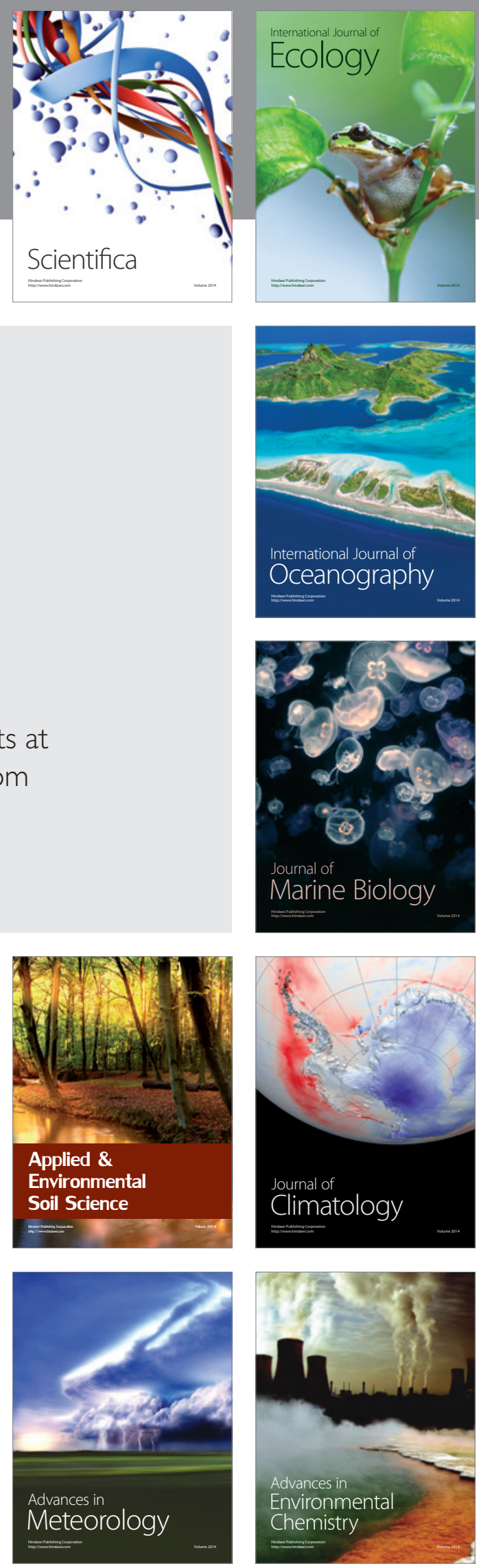